EGU21-8536, updated on 12 Apr 2021

https://doi.org/10.5194/egusphere-egu21-8536

EGU General Assembly 2021

(c) Author(s) 2021. This work is distributed under

the Creative Commons Attribution 4.0 License.

\title{
Landslides monitoring techniques review in the Geological Surveys of Europe
}

Mateja Jemec Auflič ${ }^{1,2}$, Gerardo Herrera ${ }^{3}$, Rosa María Mateos ${ }^{1,3}$, Eleftheria Poyiadji ${ }^{1,4}$, Lídia Quental $^{1,5}$, Bernardie Severine ${ }^{1,6}$, Tina Peternel $^{2}$, Laszlo Podolszki ${ }^{1,7}$, Carla ladanza ${ }^{1,8}$, Arben Kociu $^{1,9}$, Bartłomiej Warmuz $z^{1,10}$, Jan Jelének ${ }^{1,11}$, Kleopas Hadjicharalambous ${ }^{1,12}$, Gustaf Peterson Becher $^{1,13}$, Claire Dashwood ${ }^{1,14}$, Pavel Liščák ${ }^{1,15}$, Vytautas Minkevičius ${ }^{1,16}$, Saša Todorović ${ }^{1,17}$, and Jens Jørgen Møller ${ }^{1,18}$

${ }^{1}$ Earth Observation and Geohazards Expert Group (EOEG), EuroGeoSurveys, the Geological Surveys of Europe

${ }^{2}$ Geological Survey of Slovenia

${ }^{3}$ Geological Survey of Spain

${ }^{4}$ Geological Survey of Greece

${ }^{5}$ Geological survey of Portugal

${ }^{6}$ Geological Survey of France

${ }^{7}$ Geological Survey of Croatia

${ }^{8}$ Geological Survey of Italy

${ }^{9}$ Geological Survey of Austria

${ }^{10}$ Geological Survey of Poland

${ }^{11}$ Czech Geological Survey

${ }^{12}$ Geological Survey of Cyprus

${ }^{13}$ Geological Survey of Sweden

${ }^{14}$ British Geological Survey

${ }^{15} \mathrm{Geological}$ Survey of Slovakia

${ }^{16} \mathrm{Geological}$ Survey of Lithuania

${ }^{17}$ Geological Survey of Serbia

${ }^{18}$ Danish Geological Survey

Landsliding is the downslope movement of surface material under the force of gravity, initiated when gravitational and other types of shear stresses within the slope exceed the shear strength of the material that forms the slope. Often, landslides pose a physical and environmental threat to communities living in landslide-prone areas. While much landslide research focuses on monitoring techniques to define the background of the landslide (extent, volume, velocity, magnitude) one of the main goals of the Geological Surveys (GS) are to support and understand the regional and local geology to identify areas susceptible to landslides. With this perspective, a questionnaire on landslides monitoring techniques was distributed among GS of Europe to define which techniques are most widly used at GS and to distinguish those that can be considered as powerful tool for landslide mapping, monitoring, hazard analysis, and early warning, according to the type of geological settings. The initial results of the questionnaire showed that the most commonly used 
monitoring techniques are geotehnical and mapping, followed by remote sensing and hydrological techniques. Among the 849,543 landslide records evidenced by the Geological Surveys of Europe in the paper of Herrera et al. (2017), we found only 47 landslides that have been monitored. However, only landslides that directly threatning the population and infrastructure or landslides with a volume greater than $10,000 \mathrm{~m}^{3}$ have been monitored. Compared to other research (Hague et al., 2016; Froude and Petley, 2018) the questionnaire showed that the fundamental basis for any geologically-related study is geological field mapping. The results of this traditional method are commonly compiled and interpreted together with boreholes, other advanced geodetic (UAV photogrammetry, TLS, GNSS, GBInSAR), and geophysical techniques (electrical resistivity, seismic refraction, GPR). One of the critical survey findings shows on starting landslide monitoring after the failure, only $3 \%$ of observed landslides have been monitored before the occurrence. Considering these results, we evaluate the landslide-monitoring techniques and reveal different monitoring strategies between the GS of Europe.

Froude, M.J. and Petley, D. (2018) Global fatal landslide occurrence from 2004 to 2016. Natural Hazards and Earth System Sciences, 18. pp. 2161-2181

Haque U, Blum P, da Silva PF, Andersen P, Pilz J, Chalov SR, Malet J-P, Auflič MJ, Andres N, Poyiadji E, Lamas PC, Zhang W, Peshevski I, Pétursson HG, Kurt T, Dobrev N, García-Davalillo JC, Halkia M, Ferri S, Gaprindashvili G, Engström J, Keellings D (2016) Fatal landslides in Europe. Landslides $13: 1-10$

Herrera, G., Mateos, R. M., García-Davalillo, J. C., Grandjean, G., Poyiadji, E., Maftei, R., Filipciuc, T.C., Jemec Auflič, M., Jež, J., Podolszki, L., Trigila, A., Iadanza, C., Raetzo, H., Kociu, A., Przyłucka, M., 446 Kułak, M., Sheehy, M., Pellicer, X. M., McKeown, C., Ryan, G., Kopačková, V., Frei, M., Kuhn, D., 447 Hermanns, R. L., Koulermou, N., Smith, C. A., Engdahl, M., Buxó, P., Gonzalez, M., Dashwood, C., 448 Reeves, H., Cigna, F., Liščák, P., Pauditš, P., Mikulènas, V., Demir, V., Raha, M., Quental, L., Sandić, C., and Jensen, O. A. (2018) Landslide databases in the Geological Surveys of Europe, Landslides, 15, 450: 359-379. 